\title{
An Overview and Future Outlook of Indonesian Agroforestry: a Bibliographic and Literature Review
}

\author{
Budiadi $^{1}$, Aqmal N. Jihad $^{1}$, and Lina D. Lestari ${ }^{1}$ \\ ${ }^{1}$ Department of Silviculture, Faculty of Forestry, Universitas Gadjah Mada. Jl. Agro No. 1, \\ Bulaksumur, Sleman 55281, Yogyakarta, Indonesia
}

\begin{abstract}
Indonesian agroforestry has been developed along the history, since been reported that home garden was practiced from 3,000 BC in Java Island. However, agroforestry practices were recognized to have less contribution to people welfare and environmental sustainability. Bibliometric and literature studies extracting baseline information from thousands of publications were done to analyse history and future projection of Indonesian agroforestry. Research and publication on Indonesian agroforestry is steadily increasing in number and quality. Topics related with traditional land use system and ecosystem services were frequently found, and therefore classified as motor themes. There were 16 most attractive commodities stated in the publications, including palm oil and rubber. Rubber agroforest was the only system that pay interest in several decades. There were many researches on indigenous agroforestry practices in the islands, but mostly $(77 \%)$ concentrated in Java Island, especially studying private forest and home garden. The research on the issues of population pressure on forestland and efficient use of resources are the most popular topic in the decades. In the recent decade, broader theme of research was found including climate change and long-term livelihood. Based on the study, indigenous agroforestry is still important subject to study, but future roadmap of agroforestry must be developed by integrating forestry and agriculture approaches.
\end{abstract}

\section{Introduction}

Agroforestry is simply defined as a practice of managing land use by combining woody trees in the same area with crops or livestock, in a spatial or temporal arrangement [1]. In Indonesia, it was stated a groforestry system has been developed since ancient period, and the oldest a groforestry practice was home garden that developed since 3,000 BC [2], [3]. Many types of agroforestry practices were also found in all parts of the country along with population growth and social development.

Traditional or indigenous people believe that agroforestry is the most appropriate land use system in the tropical country because, in the contrary to intensive monoculture system, agroforestry is more sustainable and protect soil quality [4]. However, in fact in modem 
agriculture, the traditional practices are replaced with intensive monoculture of crops and trees [4], [5]. Agroforestry offers an approach to integrate the local knowledge with modem science. Agroforestry is always related with a system or conceptual thinking in small scale level to ga in high potentialand transformative outputs [6].

Research in agroforestry has been developed since 1980s. In general, agroforestry research was initiated with inductive reasoning and experiential thinking in the first decades. Hence, it has been more oriented on applied approach to result broader objectives related with climate change and biodiversity in 2010s [7]. In the recent situation, there was a change on defining a groforestry to be more comprehensive aims in term of study on it, for example "multifaced activities to manage multicomponent and multiproduct" [8], [9]. In order to improve the performance of tra ditional agroforestry, it is necessary to propose a systematic procedure to identify and evaluate the existing practices, by involving all attributes of productivity, ecological susta inability and social adoptability [10].

Study or resea rch on the current status of Indonesian agroforestry is a concern to promote strategy to develop future or modern agroforestry that more resource efficient align with the increasing of socio-economic and ecological problems in the country. This manuscript is a report on the retrieving or extraction process on acknowledged list of research and publication on Indonesian agroforestry within three deca des, to be involved in establishing road map of future agroforestry development in the country.

\section{Methods}

To get an in-depth understanding of status of Indonesian agroforestry, the research was conducted by using bibliometric analysis and literature review on credible sources. The bibliometric analysis indicates the evolution path or the transformation during the time frame of the research, while the literature review provides an overview of the current state of literature.

\subsection{Data collection}

Database on research of global agroforestry is available in many digital libraries. The research was conducted within April 2021 with range of published database from 1988 to 2020 of two scientific database providers, i.e., Scopus and Google Scholar. Scopus has been developed and utilized by a lmost all high-level universities [11] and Google Scholar provides open access data sets [12].

\subsection{Bibliometric analysis}

Bibliometric data analysis was extracted from Scopus by using search string "agroforest*" while symbol * improved sensitivity on variation of keywords [13]; e.g., a groforestry, a groforest, a groforester; and booleans ("OR" "AND") were not used as search string in the bibliometric data. Scopus provides checklist of instant searching steps [14]. Researching on Scopus used a determined location Indonesia, and type of publication were journals, proceedings, books, and found a number of 655 publications. The data were downloaded and converted into a format that fit to the bibliometric tools [15] and data were converted into format of BibTex and Reference Manager(RefMan).

Bibliometric is able to quantitative analysis on academic literature such as journals, authors, countries and institutions [5]. This analysis was used to know the trend of a groforestry research in Indonesia. Bibliometric analysis on Scopus data set was done using bibliometric R packages [15] and visualization of similarities (VOS) using software viewer 
[16]. Bibliometric $\mathrm{R}$ packages was used to extract information such as rate of yearly publication, number of author and frequency of citation [17]. Software R version 4.0.0 and $\mathrm{R}$ Studio 1.4.1106 was used this research with Biblioshiny Tools [18]. The results from Bibliometric R packages were annualnumber of publications (Fig. 1.), involved institutions (Fig. 2.) and strategic dia gram (Fig. 3). VOS viewer collects data set and visualizes the term of bibliographic coupling, citation, co-citation, co-authorship and co-occurrence of the keywords by authors [19]. The results from VOS viewer were keyword network cooccurrence (Fig. 4) and top ten keywords (Table 3).

\subsection{Literature Review Analysis}

Literature review in the research was focused on the traditional agroforestry practices in Indonesia, based on the previous defined traditional agroforestry in the Southeast Asian Regional Centre for Tropical Biology SEAMEO (BIOTROP) and World Agroforestry Centre (ICRAF) publications (Table 2). The research utilized some keywords (Table 4) in the Scopus and the Google Scholar within the year of 1986 to 2020, location Indonesia, and type of publications were journals, proceedings and books. Data ex traction from the Google Scholar was conducted using software Perish or Publish (PoP), to compile the reference and count scientific value of the articles [20].

Table 1. Search strings for literature review on Indonesian agroforestry

\begin{tabular}{|l|l|}
\hline Digital Library & Search strings \\
\hline Scopus & $\begin{array}{l}\text { "teak AND agroforestry" "taungya" "home garden OR homegarden" } \\
\text { "talun" "tembawang" "parak" "dusun OR dusung" "private forest" } \\
\text { "mamar" "kaliwu" "simpukng" "rubber } \\
\text { agroforestry" "pelak" "lembo" "repong damar" "damar agroforestry" }\end{array}$ \\
\hline Google Scholar & $\begin{array}{l}\text { "tumpangsari jati" "agroforestri jati" "pekarangan" "talun" "tembawang" } \\
\text { "parak" "dusu agroforestri" "hutan rakyat" "mamar" "kaliwu" } \\
\text { "simpukng" "rubber agroforestry" "pelak" "repong damar" "lembo" }\end{array}$ \\
\hline
\end{tabular}

The researching found 284 articles from the Scopus and 1691 articles from the Google Scholar. The data set was downloaded in CSV format, eliminated out-off topics on agroforestry. The researching by the Google Scholar from institutional repositories and unidentified publication year were excluded. Data elimination was done for duplicated articles in the Scopus and the Google Scholar, and compiled 1227 articles to proceed to data analysis.

The development of traditional practices in Indonesia was described by analysis of number of publications within 35 years (Table 1.). Thirty-two articles were selected to provide a comprehensive information of each a groforestry practices. The literature review in this research did not aim to systematic literature review (SLR), but to examine the previous findings with theoretical considerations [21]. 


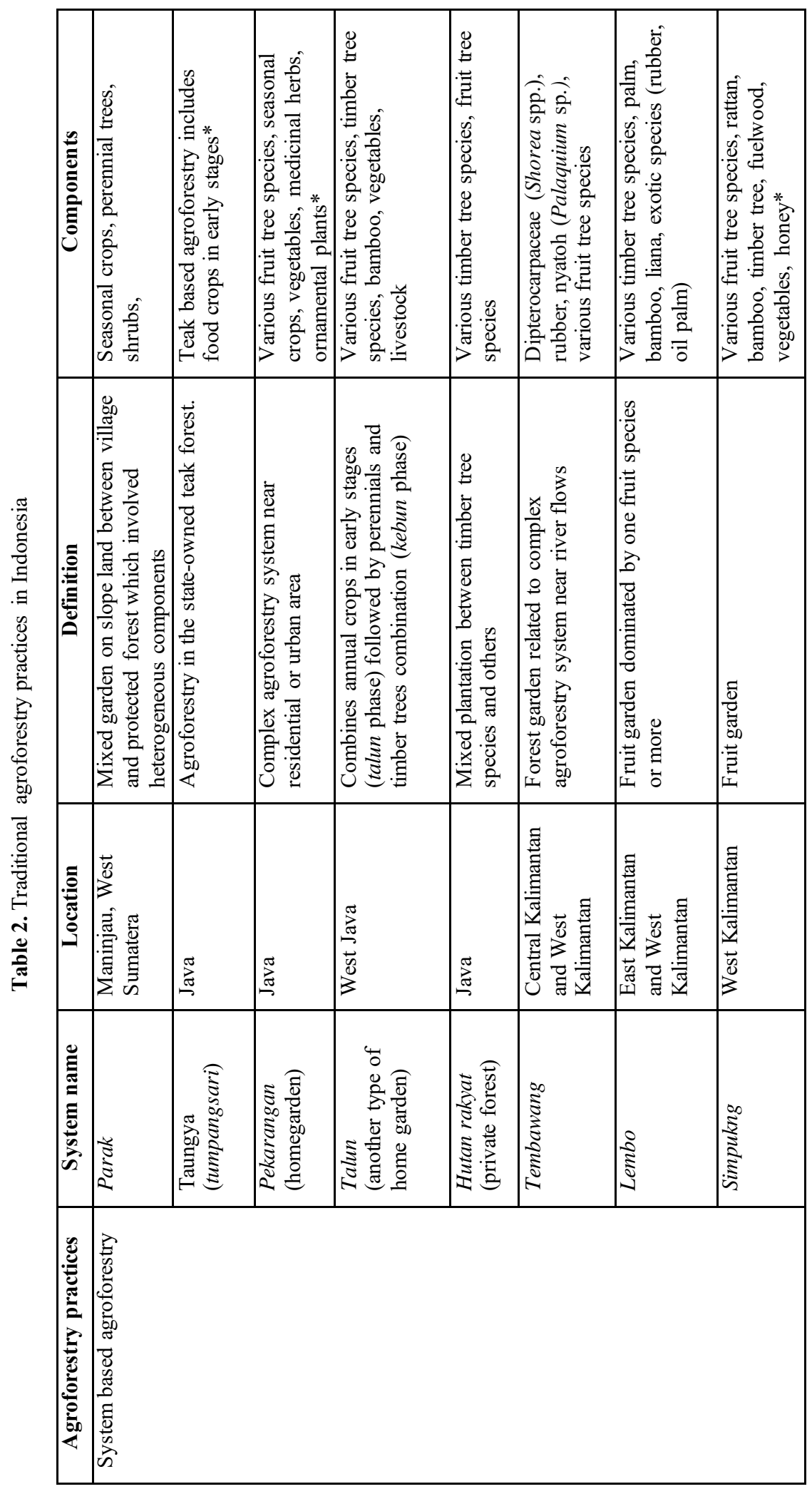




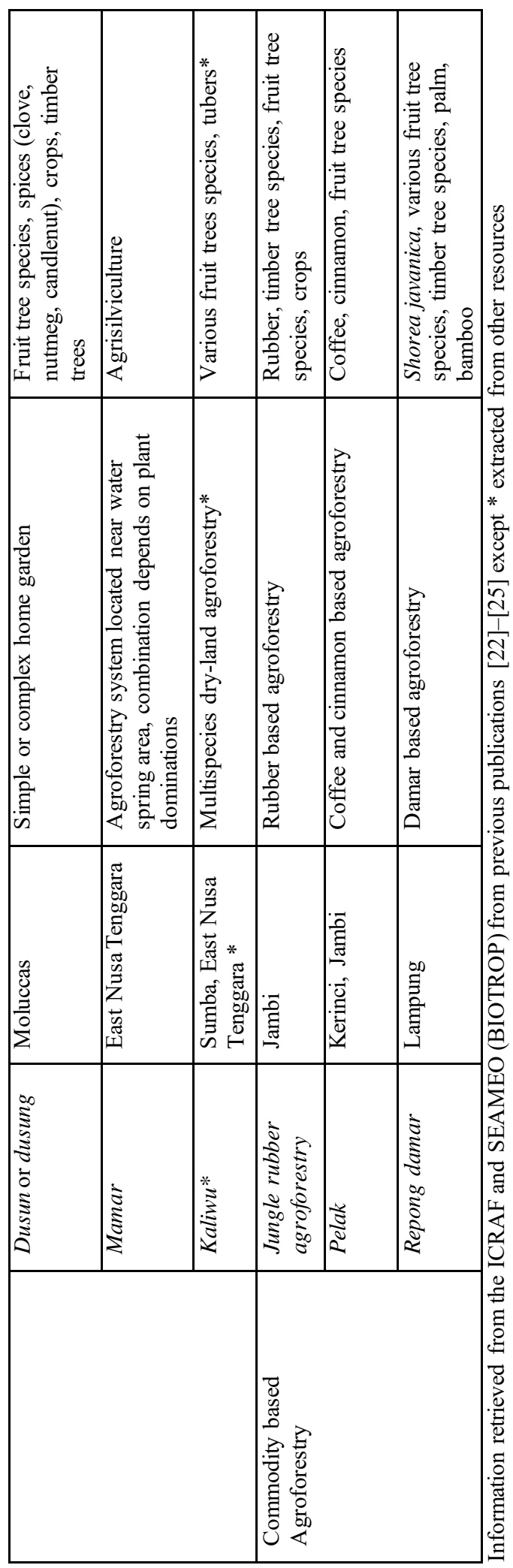




\section{Result and Discussion}

\subsection{Characteristic of Indonesian Agroforestry Research}

Research on Indonesian a groforestry has increa sed positively since the year of 1988 (Figure 1), started from one Scopus indexed publication in 1988 to the peak number of 138 publications in 2020. The third decade (2011-2020) was the period with the highest number of publications a ccounted for 490 articles or $74 \%$ of the total publica tion related a groforestry. More specifically, the last five year was the most productive publication period that accounted for $56 \%$ of the totalarticles.

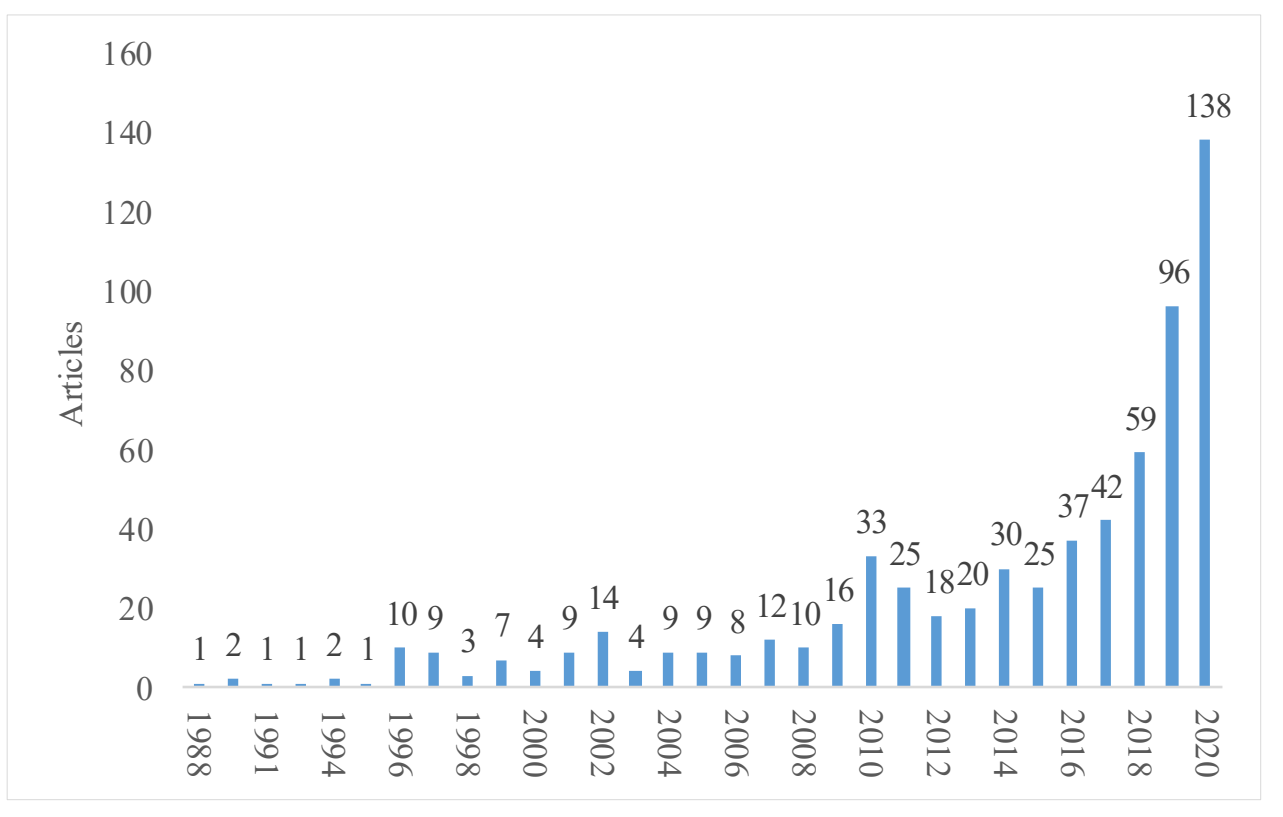

Fig. 1. Annual number of publications on Indonesian agroforestry in 1988-2020.

There were more than 200 worldwide institutions conduct publications related with Indonesian agroforestry. Figure 2 showed 20 highest ranking of institutions conduct publication on this theme. In the best five, there were two research institutes (ICRAF and CIFOR) and three universities, i.e., Goettingen University (DE), IPB university (ID) and Universitas Gadjah Mada (ID). Based on the country name, there were five country origin of the author affiliation, i.e., the Netherlands, Japan, USA and UK. 


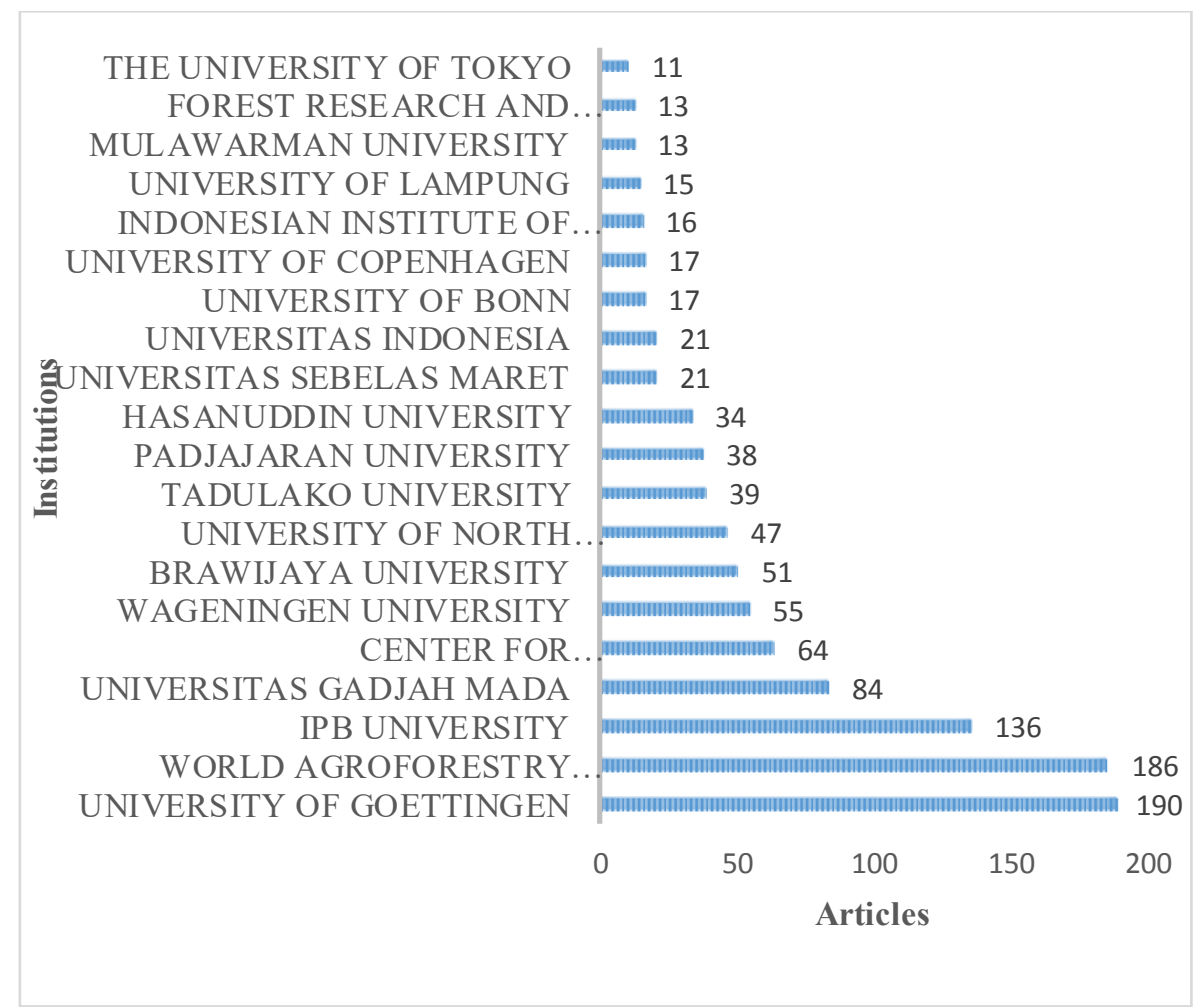

Fig. 2. Top 20 institutions in Indonesian involved in agroforestry research in 1988-2020

\subsection{Thematic and Keyword Co-occurences on Indonesian Agroforestry}

Thematic map in the bibliometric study maps the themes into the strategic diagram (Figure 3 ), showing four quadrants in the diagram, i.e., motor theme, basic theme, niche theme and emerging or declining theme [26]. Based on the figure, some number of themes related Indonesian a groforestry were developed and need attention on the quadrant of motor theme, including land use, sustainability and ecosystem services. Some of topics that under improving related with motor theme were food security, landscape management and treesoil-crop interaction. Some themes that were classified as low density and low centrality were Theobroma cacao, soil fertility and smallholder. 


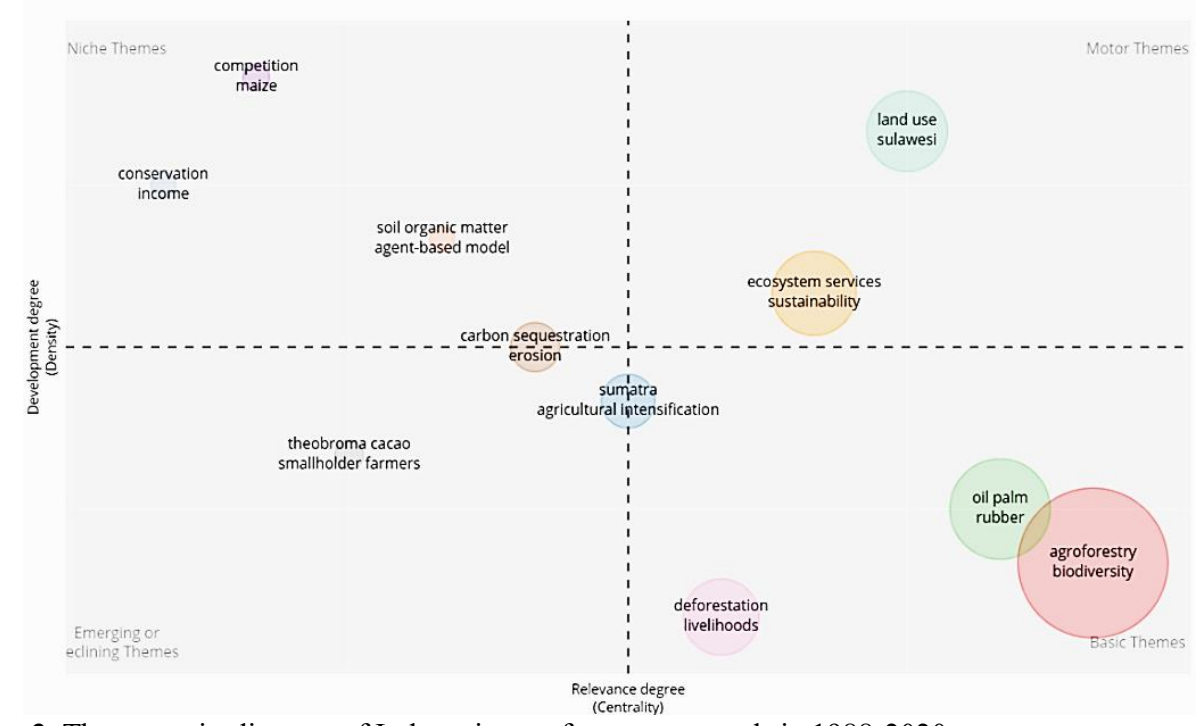

Fig. 3. The strategic diagram of Indonesia agroforestry research in 1988-2020.

Fig. 4 described variation of keywords high relevance to Indonesian agroforestry research in term of commodity and cluster of research theme. There were 16 commodities stated in the publications, and posed Elaeis guineensis (palm oil) dan Hevea braziliensis (rubber) as two most frequent object to appear. In the cluster of themes with wide network of keywords, the most frequent to appear were biodiversity, land use change, deforestation, carbon sequestration and climate change.

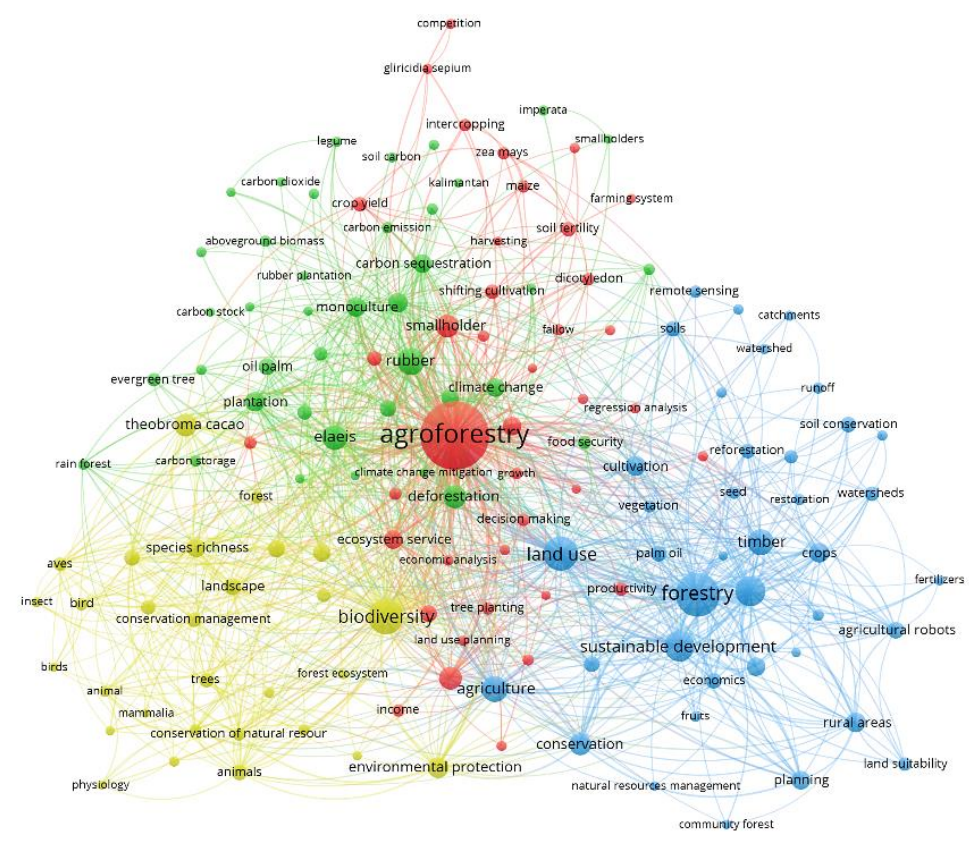

Fig. 4. Keyword co-occurrence of Indonesian agroforestry research in 1988-2020. 


\subsection{Overview of Traditional Agroforestry Practices in Indonesia}

The development of study on Indonesian agroforestry (see Figure 3 and Figure 4) were highly related with the role of local or indigenous people. Characteristics of the traditional a groforestry were high in species diversity, specific site or location, performance biased and dependency on farmer preference as well a s local tradition [27], [28]. Tra ditionala groforestry was practiced from ancient period, while rubber agroforestry and parak system has been developed in the 19th century [29], [30].

Almost all of the traditional agroforestry in Indonesia was initiated by opening natural forests, followed by crop cultivation for two to four years, and continued with forest-tree and fruit-tree planting [31]-[34], and short succession of the a groforestry occurred within 11-15year periods [35]. Some of indigenous agroforestry in different locations in Indonesia established in secondary forest ecosystem e.g., dusung (in the Mollucas), tembawang and simpukng (in Kalimantan) and repong damar and rubber agroforestry (in Sumatra) [32], [36]-[39].

Agroforestry practices outside of Java Island is an important stage in degraded land restoration, part of reforestation strategy and biodiversity conservation [40], conserve high amount of carbon [31].Traditional agroforestry is able to protect upstream and downstream areas, an example case of rubber agroforestry [41], control erosion in the repong and keliwu on hilly areas [32], [42] and conserve springs in karst soil of mamar [43].

In Java Island, taungya systems give opportunity to farmers to intercrop prior to canopy closure of the trees [44], [45]. Homegardens a re the most a dopted a groforestry system outside forest that combine annual and perennial crops, fruit trees, vegetables, herbs and orna mental flowers [46]-[49]. Community forests combine commercial trees of teak (Tectona grandis), albizia (Falcataria moluccana), gmelina (Gmelina arborea), and mahogany (Switenia macrophylla) [50]-[52]. Tra ditionalagroforestry in private land in Java aims to provide food and cash crops for farmers, and timber that managed in traditional selection system [53].

Based on the commodities, tra ditiona la groforestry produces non-timber forest products (NTFPs) such as rattan in the simpukng and lembo in Ka limantan [38], bamboo in talun in Java [33], green butter from Shorea stenoptera and resin from rubber and jelutung (Dyera sp.) and nyatoh (Palaquium sp.) in tembawang system in Kalimantan [54]. There are also NTFP of damarfrom Shorea javanica in repong damar system in Lampung [55], cinnamon bark and coffee in parak system in West Sumatra [56], as well as naturallatex from rubber agroforest in Jambi[57]. 
Table 3. The development of publication on traditional agroforestry in Indonesia in 1986-2020

\begin{tabular}{|c|r|r|r|r|r|r|}
\hline Agroforestry practices & $\begin{array}{c}\mathbf{1 9 8 6 -} \\
\mathbf{1 9 9 9}\end{array}$ & $\begin{array}{c}\mathbf{2 0 0 0 -} \\
\mathbf{2 0 0 5}\end{array}$ & $\begin{array}{c}\mathbf{2 0 0 6}- \\
\mathbf{2 0 1 0}\end{array}$ & $\begin{array}{c}\mathbf{2 0 1 1 -} \\
\mathbf{2 0 1 5}\end{array}$ & $\begin{array}{c}\mathbf{2 0 1 6}- \\
\mathbf{2 0 2 0}\end{array}$ & N total \\
\hline Java & & & & & & $\mathbf{9 5 2}$ \\
\hline taungya & 0 & 0 & 2 & 5 & 19 & 26 \\
\hline pekarangan/homegarden & 6 & 10 & 16 & 68 & 397 & 497 \\
\hline talun & 4 & 1 & 2 & 2 & 4 & 13 \\
\hline community forest & 5 & 9 & 56 & 155 & 191 & 416 \\
\hline Outside Java & & & & & & $\mathbf{2 4 8}$ \\
\hline pelak & 1 & 0 & 0 & 0 & 0 & 1 \\
\hline parak & 0 & 0 & 0 & 5 & 7 & 12 \\
\hline repong damar & 2 & 4 & 3 & 1 & 4 & 14 \\
\hline jungle rubber AF & 25 & 23 & 17 & 28 & 60 & 153 \\
\hline lembo & 1 & 0 & 0 & 1 & 4 & 6 \\
\hline tembawang & 0 & 0 & 1 & 15 & 42 & 58 \\
\hline simpukng & 0 & 0 & 3 & 1 & 0 & 4 \\
\hline dusun & 0 & 0 & 0 & 3 & 7 & 10 \\
\hline mamar & 0 & 0 & 4 & 1 & 6 & 11 \\
\hline kaliwu & 0 & 0 & 1 & 3 & 2 & 6 \\
\hline
\end{tabular}

Sustainability of traditional agroforestry is the most important consideration in the transition process to "modern" agroforestry. Based on Table 3, we learned a lack of publication on traditional agroforestry practices such as pelak, simpukng, lembo and kaliwu, and probably impacts in the low recognition to the local knowledge. There is a fact that research on agroforestry in Indonesia focused in Java Island accounted up to $77 \%$ of total publications in the decades. Refer to [58], 56.10\% of the people live in Java Island that probably related with the advance level of a groforestry practice in the island. In urban area, smallholder farmers manage the home garden more intensive than the people in rural area [7] consequently, agroforestry practices on densely populated area are more attractive to be studied than in less dense area.

\subsection{Research Theme Evolution in Indonesian Agroforestry}

Based on the bibliometric analysis, Figure 3 and Figure 4 showed broader and dyna mic of themes of a groforestry research in the recent decades. In the Table 4, there are 10 keywords that are very frequent to appear in every periods. 


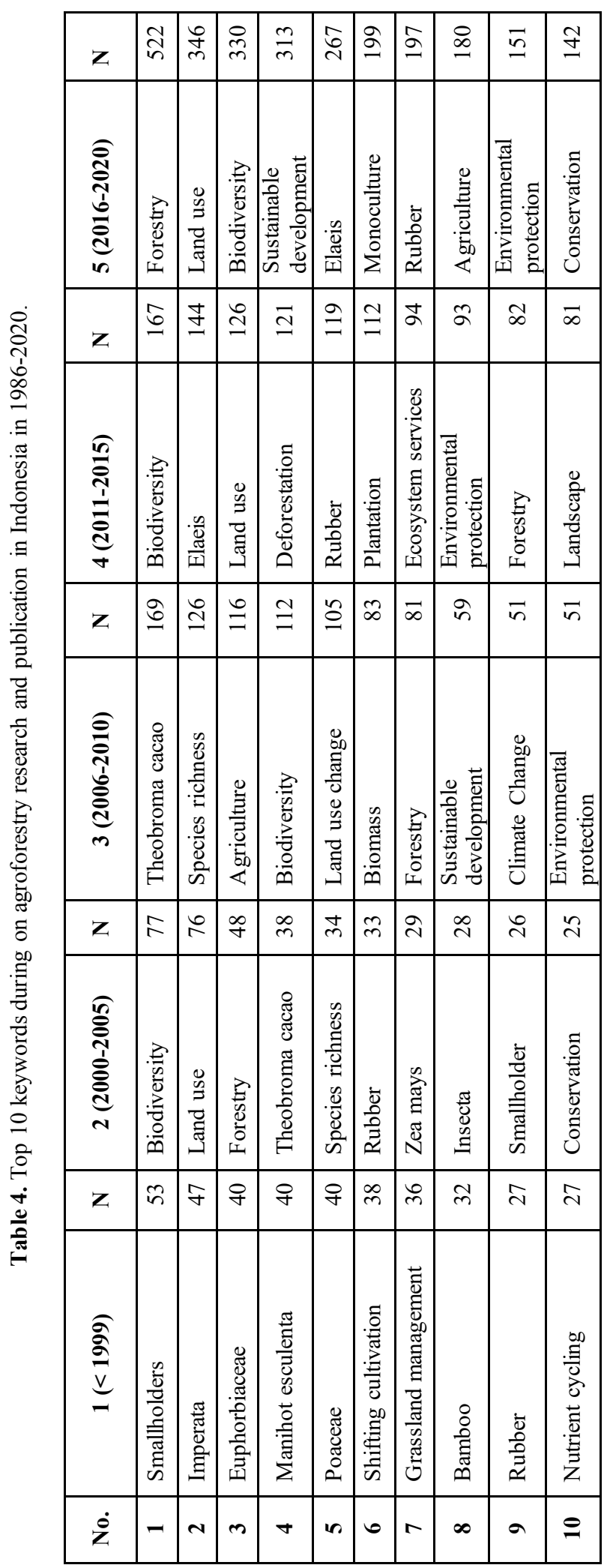


In general, there is a similar interest of the author to publish agroforestry topic in Indonesia and in Asia Pacific [59]. Based on the study of agroforestry evolution, changes on global issues impacted in the most selected theme or topic on Indonesian agroforestry, including pathways of discourses on forestry field in 1970s to 2000s that consist of poverty and economic, environmental and ecosystem services, deforestation, biodiversity conservation and susta inable development [60].

In the global scope, development of a groforestry topics contributed to two main group of fields, i.e., natural science and social science [5]. This impacted on the broader applied science including improvement of farm productivity, impact on biodiversity, climate change strategy, as well as increasing welfare [61]-[63]. The development of agroforestry science was also affected by farmer behaviour to choose a groforestry system or commodities. Farmer attitude to respond the possible risks affected the choice of a groforestry practice [64].

Based on the evolution of agroforestry topics, jungle rubber was the only system that found in four periods or decades (1, 2, 4 and 5) with increasing number of publications in each period. The system may support Indonesia rubber production, that recognized as the second biggest latex producer (22\% of the totalworld) following Thailand [65]. Rubber was introduced in the first 19th century in Jambi [7] and improved rubber agroforestry system (RAS) was practiced in 1994 by ICRAF and CIRAD in three different locations in Sumatra and Ka limantan[66].

\subsection{Future Outlook of Indonesian Agroforestry}

Our analysis convinced that Indonesian agroforestry development will be more challenged by increase of socio-economic and ecological problems, a long with broader up the objectives to solve the local to global issues. Factors of people knowledge, investment and germplasm quality were able to decline adoption of agroforestry [67]. On the other hand, many indigenous agroforestry needs scientific improvements and innovative treatments.

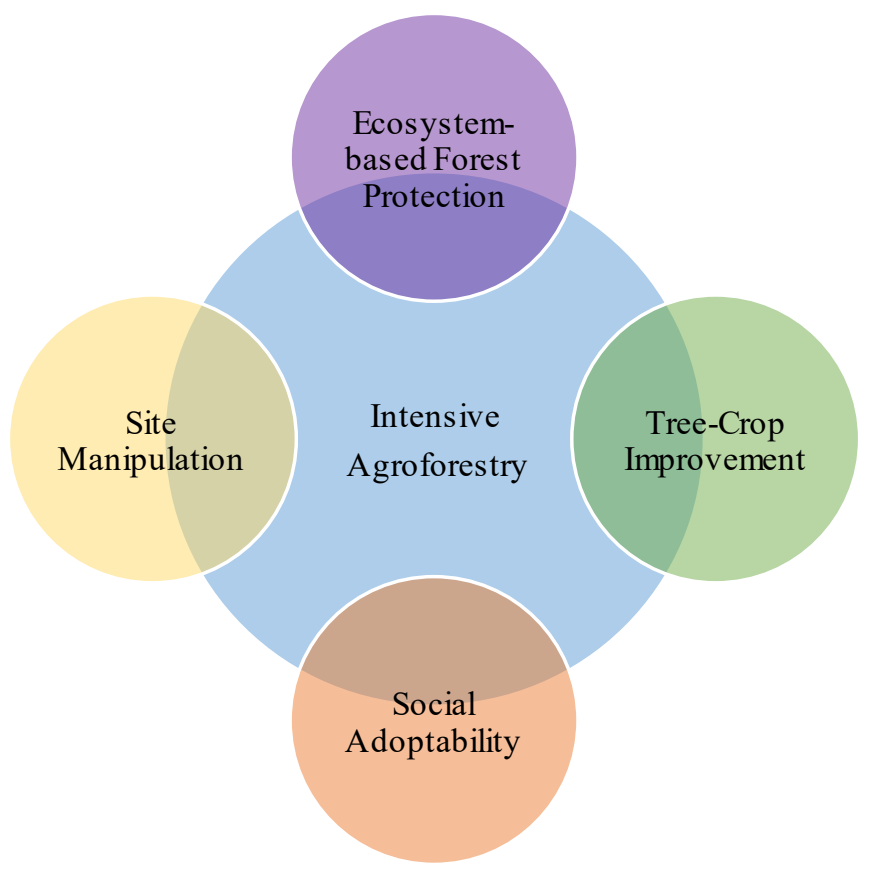

Fig. 5. Conceptual framework of Intensive Agroforestry 
Intensification has been implemented in both a griculture and forestry as separated fields. Agriculture intensification aimed to fulfil basic need of food for the increasing population, especially in Java Island [68], [69]. It comprised of sets of treatments on farmland such as irrigation, utilization of high-quality seeds and pesticide, as well as technical assistance [70], but probably affected land degradation [71]. On forestry field, intensive silviculture that consists of tree improvement, site manipulation and plant protection [72], has been applied to improve timber production [73].

Intensification on the both fields may result in gaps to the newly paradigm or concept on integration of land use [74]. Therefore, a new approach namely intensive agroforestry is promoted to combine two existing land-use techniques of intensive silviculture and agronomy. The concept concerns to develop science and technology of seasonal crop cultivation that adaptable to forestry systems. The intensive a groforestry can be practiced to gain both socio-economic and ecological objectives.

\section{References}

1. S. Viswanath, P. A. Lubina, S. Subbanna, M. Sandhya, Adv. Agric. Res. Technol.II, 1 (2018)

2. O. Soemarwoto, in Agroforestry: a Decade Development, H. A. Steppler and P. K. R. Nair, Eds. InternationalCouncil for Research in Agroforestry, (1987)

3. K. F. Wiersum, in Tropical Homegardens: A Time-Tested Example of Sustainable Agroforestry, B. M. Kumarand P. K. R. Nair, Eds. Springer Netherlands, (2006)

4. M. Lovrić, M. Rois-Díaz, M. den Herder, A. Pisanelli, N. Lovrić, P. J. Burgess, Agrofor. Syst.92, 4 (2018)

5. W. Liu, S. Yao, J. Wang, M. Liu, Sustain.11, 12 (2019)

6. A. Steiner, in Agroforestry - The Future of Global Land Use, Advances i., P.K.R. Nair and D. Garrity, Ed. Springer Dordrecht Heidelberg New York London, (2012)

7. Na ir, D. Garrity, in Agroforestry - The Future of Global Land Use, 9, 11, B. M. Kumarand P. K. R. Nair, Eds. The Netherlands, (2012)

8. O. I. Ollinaho, M. Kröger, J. Rural Stud.82 (2021)

9. A. Jerneck, L. Olsson, J. Rural Stud.32 (2013)

10. P. K. R. Nair, J. C. Dagar, Agrofor. Syst.16, 1 (1991)

11. A. W. Harzing, S. Alakangas, Scientometrics106, 2 (2016)

12. A. Martín-Martín, R. Costas, T. Van Leeuwen, E. Delgado López-Cózar, J. Informetr.12,3 (2018)

13. S. Kugley, A. Wade, J. Thomas, Q. Mahood, A. K. Jørgensen, K. Hammerstrøm, N. Sathe, Campbell Syst. Rev.13, 1 (2017)

14. J. Stapleton, C. Carter, L. Bredahl, J. Acad. Librariansh.46, 5 (2020)

15. M. Aria, C. Cuccurullo, J. Informetr.11, 4 (2017)

16. N. J. van Eck, L. Waltman, Scientometrics84, 2 (2010)

17. H. Liu, F. Kong, H. Yin, A. Middel, X. Zheng, J. Huang, H. Xu, D. Wang, Z. Wen, Build. Environ.196, March (2021)

18. S. Ramanan S., A. K. George, S. B. Chavan, S. Kumar, S. Jayasubha, Ind. Crops Prod.158, July (2020)

19. J. M. Merigó, W. Pedrycz, R. Weber, C. de la Sotta, Inf. Sci. (Ny).432 (2018)

20. M. Franceschet, Scientometrics83, 1 (2010)

21. L. Westholm, M. Ostwald, Agrofor. Syst.94, 2 (2020)

22. H. S. Arifin, M. A. Sardjono, L. Sundawati, T. Djogo, G. A. Wattimena, Widianto, Bahan Ajar Agroforestri (2003)

23. K. Hairiah, M. A. Sardjono, S. Sabarnurd in, Bahan Ajaran Agroforestri 1 (2003) 
24. G. Michon, H. de Foresta, Ketika kebun berupa hutan: Agroforest Khas Indonesia Sebuah sumbangan masyarakat (1993)

25. G. M. dan W. D. H de Foresta, A Kusworo, Ketika kebun berupa hutan: Agroforest Khas Indonesia Sebuah sumbangan masyarakat.(2002)

26. M. J. Cobo, A. G. López-Herrera, E. Herrera-Viedma, F. Herrera, J. Informetr.5, 1 (2011)

27. B. Doddbasawa, Chittapur, M. Murthy, Bangladesh J. Bot. 47, 4 (2018)

28. P. K. R. Nair, in Conference of Agricultural and Rural Development Officiers of the Asia Mission of USAID, Los Baños (Filipinas), 22-26 Apr 1985, 2008, 12686

29. T. Martial, Uninet Biosci. Conf.Vol 2 No 1 (2012)

30. B. Leimona, L. Joshi, Proj. Final Rep. (2010)

31. D. Astiani, Ripin, Biodiversitas17, 1 (2016)

32. N. F. Istia wati, S. Susilo, Budijanto, I. Nyoman Ruja, S. Widodo, IOP Conf. Ser. Earth Environ. Sci.412, 1 (2020)

33. K. Mizuno, S. S. Mugniesyah, A. S. Herianto, H. Tsujii, Southeast Asian Stud.2, 2 (2013)

34. M. Kaya,L. Kammesheidt, H. J. Weidelt, Agrofor. Syst.54, 3 (2002)

35. J. O. B. Christine E. Blinn, M. A. Pedlowski, R. H. W. A, Appl. Geogr.43 (2013)

36. E. Insusanty, M. Ikhawan, E. Sadjati, IOP Conf. Ser. Earth Environ. Sci.156, 1 (2018)

37. Rafdinal, R. Pitopang, J. Phys. Conf. Ser.1242, 1 (2019)

38. E. Mulyoutami, R. Rismawan, L. Joshi, For. Ecol. Manage.257, 10 (2009)

39. T. M. Silaya, L. Siahaya, Int. J. Sci. Technol. Res.9, 5 (2020)

40. F. Montagnini, R. Metzel, Integrating Landscapes: Agroforestry for Biodiversity Conservation and Food Sovereignty, 12, March.(2017)

41. E. Insusanty, M. Ikhawan, E. Sadjati, in IOP Conference Series: Earth and Environmental Science, 156, 1(2018)

42. G. N. Njurumana, J. Pemuliaan Tanam. hutan 13,2 (2019)

43. Dua K.S.Y.Klass, J Mns. dan Lingkung.Vol. 16, N (2009)

44. R. Rohdewohld, Public administration in Indonesia. Monash University Press, (1995)

45. J. Szulecka, K. Obidzinski, A. Dermawan, Forest Policy and Economics, 62. (2016)

46. J. Iskandar, B. S. Iskandar, R. Parta sa smita, Biodiversitas17, 1 (2016)

47. L. Hakim, N. R. Pamungkas, K. P. Wicaksono, Soemarno, Agrivita 40, 3 (2018)

48. T. P. Agustina, Nisyawati, E. B. Walujo, in AIP Conference Proceedings, 2120 (2019)

49. Y. B. Prastiyo, R. L. Kaswanto,H. S. Arifin, IOP Conf. Ser. Earth Environ. Sci.477, 1 (2020)

50. R. R. Sari, K. Hairiah, Suyanto, J. Ekon. Pertan. dan Agribisnis2, 2 (2018)

51. D. S. Martono, S. Rahayu, Agri-Tek 17, 2 (2017)

52. Y. Indrajaya, M. Siarudin, J. Penelit. Sos. Ekon. Kehutan.Vol. 12 No (2015)

53. S. Nur, I. Lestari, Y. Hero, 09, 3 (2018)

54. Sumarhani, T. Kalima, 1, Sundawati 1993 (2015)

55. G. Schroth, M. do Socorro Souza da Mota, Encycl. Agric. Food Syst.1 (2014)

56. Y. Aumeeruddy, B. Sansonnens, Agrofor. Syst.28, 2 (1994)

57. S. F. Kennedy, B. Leimona,Z.-F. Yi, Int. J. Biodivers. Sci. Ecosyst. Serv. Manag.13, 1 (2017)

58. BPS, Potret Sensus Penduduk2020 Menuju Satu Data Kependudukan Indonesia. Badan Pusat Statistik, (2020)

59. S. Shin, K. T. Soe, H. Lee, T. H. Kim, S. Lee, M. S. Park, Forests11, 4 (2020)

60. B. Arts, M. Appelstrand, D. Kleinschmit, H. Pülzl, I. Vissen-Hamakers, R. Eba'a Atyi, T. Enters, K. Mcginley, Y. Yasmi, Embrac. Complex. Meet. challenges Int. For. Gov.28 (2010)

61. J. P. Basu, New Zeal. J. For. Sci.44, 1 (2014) 
62. J. Y. Coulibaly, B. Chiputwa, T. Nakelse, G. Kundhlande, Agric. Syst.155, March (2017)

63. J. Haggar, D. Pons, L. Saenz, M. Vides, Agric. Ecosyst. Environ.283, (2019)

64. E. Gosling, T. Knoke, E. Reith, A. Reyes Cáceres, C. Paul, Environ. Manage. (2021)

65. van Noordwijk M, C. R, S. FL, in In: van Noordwijk M, ed. Sustainable development through trees on farms: agroforestry in its fifth decade., 2019

66. E. Penot, in Book of abstracts of the 2nd World Congress of Agroforestry, 23-28 August 2009, Nairobi, Kenya, WCA (2009)

67. P. Kiyani, J. Andoh, Y. Lee, D. K. Lee, Forest Sci. Technol.13, 4 (2017)

68. F. Agus, J. Penelit. dan Pengemb. Pertan.30, 4 (2011)

69. L. Potter, Asia Pac. Viewp.42, 2-3 (2001)

70. Erwidodo, G. Wittwer, R. Stringer, Indones. a Reforming World Econ. Eff. Agric. Tra de Environ.May 2021 (2009)

71. P. M. Kopittke, N. W. Menzies, P. Wang, B. A. McKenna, E. Lombi, Environ. Int.132, May (2019)

72. Soekotjo, Teknik Silvikultur Intensif (SILIN), 1st ed. UGM Press, 2009

73. P. H. S. Brancalion, O. Campoe, J. C. T. Mendes, C. Noel, G. G. Moreira, J. van Melis, J. L. Stape, J. Guillemot, Ecol. Appl.29, 2 (2019)

74. M. van Noordwijk, R. Coe, F. L. Sincla ir, Sustainable development through trees on farms: (2019) 